\title{
MIMESIS
}

VOL. 3. No. 1, Januari 2022

\section{ANALISIS SEMIOTIKA PIERCE: PERBANDINGAN POSTER IKLAN SAMPO DI TIONGKOK DAN INDONESIA}

\section{Li Kunmei}

Program Studi Magister Ilmu Linguistik, Fakultas Ilmu Budaya, Universitas Padjadjaran kunmei20001@mail.unpad.ac.id

\section{Dian Indira}

Program Studi Magister Ilmu Linguistik Fakultas Ilmu Budaya, Universitas Padjadjaran dian.indira@unpad.ac.id

\section{Ypsi Soeria Soemantri}

Program Studi Magister Ilmu Linguistik, Fakultas Ilmu Budaya, Universitas Padjadjaran ypsi.soerias@gmail.com

\section{Riza Lupi Ardiati}

Program Studi Magister Ilmu Linguistik, Fakultas Ilmu Budaya, Universitas Padjadjaran riza.lupi@unpad.ac.id

\section{ARTICLE INFO}

ABSTRACT

\section{Article history}

Received 13 January 2022

Revised 28 January 2022

Accepted 29 January 2022

Keywords

Shampoo Advertisement

Indonesia-China

Semiotics

Character

Society
Advertisements are packaged in such a way that it is very influential to convey messages and at the same time influence or suggest products to the public. In shampoo advertisements from one country to another, there are cultural peculiarities of the people. This research has a problem formulation, namely the character of shampoo advertising culture in China and Indonesia. In solving the problem formulation, this research uses Pierce's semiotic theory using data in the form of advertisements for the Pantene, Clear, and Sunsilk shampoo brands. The analysis is carried out with a qualitative method. The results of this study show that shampoo advertisements in China and Indonesia in general have similarities with displaying a picture of a woman, but both have their own character that shows a picture of the people of their respective countries.

This is an open access article under the CC-BY-SA license.

\section{Article history}

Received 13 Januari 2022

Revised 28 Januari 2022

Accepted 29 Januari 2022

\section{Keywords}

Iklan sampo

Indonesia-Tiongkok

Semiotik

Karakter

Masyarakat
Iklan dikemas sedemikian rupa sangat berpengaruh untuk menyampaikan pesan dan sekaligus memengaruhi atau mensugestikan produk kepada masyarakat. Dalam iklan sampo satu negara dengan negara yang lain terdapat kekhasan budaya masyarkatnya. Penelitian ini memiliki rumusan masalah yaitu karakter budaya iklan sampo di Tiongkok dan Indonesia. Dalam menyelesaikan rumusan masalah, penelitian ini menggunakan teori semiotika Pierce dengan menggunakan data berupa iklan merek sampo Pantene, Clear, dan Sunsilk Analisis dilakukan metode kualitatif. Hasil dari penelitian ini bahwa iklan sampo di Tiongkok dan Indonesia secara umum memiliki kesamaan dengan menampilkan gambar seorang peremppuan namun keduanya memiliki karakter sendiri yang memperlihatkam gambaran masyarakat dari negara masing-masing.

This is an open access article under the CC-BY-SA license. 


\section{PENDAHULUAN}

Persaingan market di suatu negara tidak lepas dari budaya masyarakat negara tersebut. Pemasaran yang dilakukan berguna untuk menarik perhatian masyarakat. Perhatian masyarakat dapat didapatkan dengan adanya memasang iklan di media massa. Kasali (1995: 9) menjelaskan bahwa iklan merupakan salah satu media komunikatif untuk menyampaikan pesan dari produsen kepada konsumen. Maka, kegiatan beriklan harus lebih dari sekedar memberikan informasi tentang produk yang ditawarkan tapi dapat membuat konsumen tertarik untuk membeli.

Dalam pemasaran ini, media massa memiliki peran penting, dan aspek terkuat untuk memengaruhi khalayak supaya mengonsumsi produk yang ditawarkan. Sehingga tidak dapat dipungkiri semua produk sangat memerlukan iklan, salah satunya produk sampo. Peneliti berfokus pada iklan sampo berupa poster karena poster dianggap memiliki kompleksitas dibalik sebuah pesan visual sederhana yang terdiri atas bahasa dan grafis. Kompleksitas dalam segala aspek pemaknaan tersebut yang membuat iklan tersebut utuh. Kompleksitas iklan dalam poster membuat penulis merasa perlu untuk melakukan penelitian lebih lanjut mengenai perbandingan iklan sampo di Tiongkok dan Indonesia.

Dalam memahami pemaknaan iklan secara utuh, peneliti mengambil beberapa merek sampo yang cukup terkenal di negara Tiongkok dan Indonesia. Pemaknaan ini dianggap mampu memberikan perbandingan antara iklan sampo di Tiongkok dan Indonesia. Iklan sampo yang dipilih di antaranya adalah sampo pantene, sunsilk/hazeline, dan clear. Pemaknaan iklan yang dihasilkan secara utuh diharapkan mampu menggambarkan kecenderungan unsur yang terkandung dalam poster iklan sampo. Hal ini dapat digunakan untuk mengetahui perbandingan cara mengiklankan produk sampo di negara Indonesia dan Tiongkok.

Pemaknaan iklan sampo menggunakan teori semiotika Charles Sanders Pierce (selanjutnya akan disebut semiotika Pierce) karena data yang diambil dianggap sesuai dengan teori tersebut. Konsep semiotika Pierce menyatakan bahwa semiotika merupakan suatu tindakan (action), pengaruh, (influence), atau kerjasama dari tiga subjek, antara lain tanda (sign), objek dan interpretant (Piliang, 2010: 266-267). Diharapkan dengan adanya penelitian ini mampu menciptakan strategi iklan-iklan baru, utamanya dalam produk sampo yang lebih bermakna.

Berdasarkan latar belakang di atas, rumusan masalah dalam penelitian ini yaitu, bagaimana makna dan perbandingan iklan sampo di Tiongkok dan Indonesia? Sesuai dengan 
permasalahan tersebut memiliki dua tujuan. Pertama, mendeskripsikan makna yang terkandung dalam iklan sampo di Tiongkok dan Indonesia. Kedua, menjelaskan perbandingan unsur yang ada dalam iklan sampo di Tiongkok dan Indonesia. Selanjutnya, penelitian ini memiliki manfaat teoritis dan praktis. Secara teoritis manfaat penelitian ini adalah dapat digunakan sebagai nilai tambah dan wawasan dalam ranah dalam pembahasan pemaknaan menggunakan semiotika Pierce, utamanya dalam produk iklan. Kemudian, untuk manfaat secara praktis penelitian ini dapat digunakan sebagai tinjauan pustaka atau referensi dalam melaksanakan penelitian berikutnya serta, menjadi sumber bacaan yang kredibel.

Beberapa peneliti telah melakukan penelitian tentang iklan dengan menggunakan teori semiotic dari Pierce. Penelitian tersebut di antaranya jurnal "Perbandingan Brand Equity Produk Sampo Merek Sunsilk dengan Merek Pantene" (Aristyani \& Nyoman, 2013). Penelitian ini bertujuan untuk mengetahui perbedaaan brand equity beserta elemen-elemennya antara produk sampo merek Sunsilk dengan merek Pantene. Selain mengetahui brand equity-nya, teknik analisis data yang digunakan pada penelitian ini adalah uji beda mean dengan sampel berpasangan. Berdasarkan hasil penelitian yang tersebut bahwa tidak terdapat perbedaan ekuitas merek antara sampo Sunsilk dengan Pantene. Dari empat dimensi ekuitas merek, hanya satu yang berbeda, yaitu brand perceiverd quality. Oleh karena itu, ke depan sampo merek Sunsilk harus lebih berfokus pada peningkatan kualitas produk dengan cara inovasi dalam aroma, bahan, kandungan, dan mutu keseluruhan sehingga mampu bersaning dan berada pada posisi top brand bersama merek Pantene. Penelitian yang telah dijelaskan ini memiliki kesamaan pada merek produk yang digunakan, yaitu Pantene dan Sunsilk. Namun, penelitian tersebut dikaji dari bidang kajian ilmu komuniksi bukan dari bidang kajian ilmu linguistik. Kebaruan dari penelitian yang dikerjakan tim penulis membahasa sisi lain dari sampo dengan merek Sunsilk dan Pantene.

Selanjutnya, jurnal penelitian dengan judul "Kajian Semiotika Charles Sanders Pierce: Relasi Trikotomi (Ikon, Indeks dan Simbol) dalam Cerpen Anak Mercusuar Karya Mashdar Zainal" (Wulandari \& Erik, 2020). Penelitian ini bertujuan untuk menjelaskan, menganalisis, serta mendeskripsikan unsur ikon, indeks dan simbol dalam cerpen Anak Mercusuar karya Mashdar Zainal. Selain ikon, indeks, dan simbol, penelitian ini juga menjelaskan relasi antara tanda-tanda dalam cerpen tersebut. Penggunaan metode dalam penelitian ini metode kualitatif. Dengan teknik penulisan deskriptif. Hasil yang didapatkan berupa 4 tanda dalam bentuk ikon, 6 tanda dalam bentuk indeks, dan 3 tanda dalam bentuk simbol. Penelitian ini berfokus kepada karya sastra yang berupa novel, berbeda dengan penelitian yang dilakukan 
tim penulis yaitu meskipun teori yang digunakan sama, yaitu semiotika Pierce. Dengan adanya perbedaan dan persamaan yang telah disebutkan sebelumnya, diharapkan penelitian ini mampu menjadi salah satu pembuktian bahwa teori Pierce dapat digunakan pada iklan. Hal ini juga mampu mengembangkan penggunaan teori semiotika Pierce.

Penelitian selanjutnya, masih terkait dengan teori semiotika Pierce dan iklan, yakni jurnal penelitian dengan judul "Representasi Pakaian Muslimah dalam Iklan, Analisis Semiotika Charles Sanders Pierce Pada Iklan Kosmetik Wardah di Tabloid Nova" (Dewi, 2013). Penelitian ini memiliki latar belakang bahwa merek kosmetik Wardah yang awal melakukan branding produknya dengan label halal. Oleh karena itu, Wardah membangun imajinasi religius dalam iklannya, salah satunya dengan menggandeng brand ambassador hijab atau busana muslim. Dengan analisis berdasarkan semiotik Charles Sanders Pierce, penelitian ini meyakini bahwa cara berpakaian merupakan salah satu bentuk komunikasi. Melalui pakaian, seseorang dapat menyampaikan pesan kepada orang lain, yang digunakan pencitraan produk Wardah. Hasil yang dapat diambil dari penelitian ini adalah busana muslim pada iklan Kosmetik Wardah direpresentasikan melalui penggunaan busana yang menutupi aurat namun tetap stylish dan fashionable, sehingga memperkuat citra Islam modern yang dibangun oleh Wardah.

Masih terkait dengan penggunaan teori semiotika Pierce tetapi dalam ilmu lain, pada penelitian ini terkait dengan ilmu sejarah. Jurnal penelitian berjudul "Analisis Semiotik Charles Sanders Pierce tentang Taktik Kehidupan Manusia: Dua Karya Kontemporer Putu Sutawijaya” (Albar, 2018). Penelitian tersebut mengkaji representasi taktik kehidupan manusia dalam dua karya seni rupa kontemporer Putu Sutawijaya sebagai proses perjalanan kreatif sang seniman kontemporer melalui lintasan ide-ide budaya visualnya dalam kuratorial Betwixt and Between.

Taktik kehidupan dalam penelitan ini dijelaskan bahwa seseorang (seniman) mampu secara cepat mengeksekusi problematika kehidupan (masyarakat) sebagai representasi strategi keberhasilan kehidupan keluarganya dalam jangka panjang. Dalam penelitian tersebut juga ditemukan bahwa Putu Sutawijaya memiliki konsep yang konsisten dan memiliki otoritas penuh dalam proses kreatif melalui pengalamannya yang mampu memberikan wacana dan sublimasi dalam seni rupa kontemporer di Indonesia. Dengan menggunakan analisis strukturis Christoper Lloyd, Putu Sutawijaya sebagai agency senantiasa menerapkan sikap kesunyian (niharamkarah) dalam kehidupan realitas keseharian manusia (ajaran Hindu) dalam 
mempertahankan dan membentuk kehidupan yang harmonis. Cara pemaparan peneliti sedikit berbeda, yakni filosofis dan mengandung banyak pemaknaan. Hal ini menunjukkann bahwa teori semiotika Pierce mampu digunakan untuk mencari makna mendalam pada sebuah karya. Setidaknya hal ini menjadi pertimbangan peneliti bahwa teori semiotika Pierce sangat mampu digunakan untuk mencari perbandingan iklan sampo di Tiongkok dan Indonesia dengan pembahasan makna yang cukup mendalam.

\section{METODE}

Metode penelitian yang digunakan untuk menemukan hasil perbandingan produk iklan sampo di Tiongkok dan Indonesia termasuk dalam kajian pustaka dengan menerapkan metode kualitatif. Gorman dan Clayton (Kuswarno, 2009) menjelaskan bahwa metode kualitatif adalah melaporkan meaning of events dari apa yang diamati. Ditambahkan oleh Ratna (2008: 47), metode kualitatif yang berfokus terhadap data alamiah dalam hubungannya dengan konteks keberadaannya. Dalam hal ini, data alamiah yang dimaksud adalah bahasa dan grafis dalam poster iklan sampo yang telah disediakan oleh penulis.

Berkaitan dengan penelitian kebahasaan yang dilakukan, perhatian penelitian kualitatif berfokus pada elemen manusia, objek, dan institusi, serta hubungan atau interaksi di antara elemen-elemen tersebut, dalam upayanya memahami suatu peristiwa, perilaku, atau fenomena (Mohamed \& Ahmad, 2010). Hal ini juga sesuai dengan metode kualitatif yang digunakan dalam penelitian bahasa, bahwa dalam metode kualitatif menyajikan secara langsung data kebahasaan yang didapat dari hasil lapangan berdasarkan penggunaannya. Metode penelitian kualitatif juga mencerminkan adanya suatu perspektif fenomenologis. Selain hal-hal yang telah disebutkan sebelumnya, dapat dijelaskan bahwa metode kulitatif berusaha memahami makna dari peristiwa dan interaksi manusia dalam situasi tertentu. Dari pemahaman makna akan diperoleh konseptual serta kontruksi dalam kehidupan bersosial (Zalim, 2014: 13).

Dalam penelitan ini pengamatan dilakukan terhadap tiga iklan sampo khususnya merek sampo yang ditemukan di Tiongkok dan Indonesia. Poster iklan sampo yang digunakan dalam penelitiaan ini adalah merek sampo Sunsilk/Hazeline, Pantene dan Clear. Berdasarkan penjelasan di atas, bahwa bahasa dan grafis dalam poster iklan sampo sangat bisa untuk dilakukan analisis menggunakan metode kualitatif. Tahapan pertama akan dipilah berdasarkan 


MIMESIS
Universitas
Ahmad Dahlan $\quad$ VOL. 3o. 1, Januari 2022

bahasa yang digunakan dalam poster. Kemudian, data bahasa yang ditemukan akan dikaitkan dengan grafis yang berupa gambar maupun desain yang ada dalam poster.

Tabel 1. Contoh Ikon, Indeks dan Simbol

\begin{tabular}{|l|l|l|}
\hline $\begin{array}{c}\text { Jenis } \\
\text { Tanda }\end{array}$ & \multicolumn{1}{|c|}{ Hubungan antara Tanda dan sumber acuannya } & \multicolumn{1}{|c|}{ Contoh } \\
\hline Ikon & $\begin{array}{l}\text { Tanda yang penanda dan petandanya, keduanya } \\
\text { memiliki sifat alamiah }\end{array}$ & Peta, foto, \\
\hline Indeks & $\begin{array}{l}\text { Tanda penunjuk antara hubungan alamiah yang bersifat } \\
\text { sebab akibat }\end{array}$ & $\begin{array}{l}\text { Asap merupakan tanda } \\
\text { adanya api }\end{array}$ \\
\hline Simbol & $\begin{array}{l}\text { Tanda yang menunjukkan antara penanda dan petanda } \\
\text { bersifat arbitrer }\end{array}$ & Perjanjian masyarakat \\
\hline
\end{tabular}

Kemudian, merujuk pada konsep segitiga makna Pierce, model triadik Pierce ini memperlihatkan tiga elemen utama pembentuk tanda, yaitu representamen (sesuatu yang merepresentasikan sesuatu yang lain), objek (sesuatu yang direpresentasikan) dan interpretant (interpretasi seseorang tentang tanda) (Piliang, 2010: 266-267). Berikut gambarnya.

\section{Diagram 1 : Konsep Segitiga Makna Semiotika Pierce}

(Sumber: Piliang, 2010)

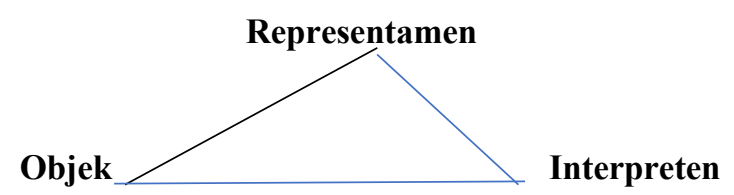

\section{PEMBAHASAN}

Dalam pembahasa data berupa iklan sampo akan dikelompokkkan menjadi dua, kelompok pertama sampo Sunsilk atau Hazeline, Pantene dan Clear versi Indonesia dan kelompok kedua versi Tiongkok. Di dalam penelitian ini sampo merek Sunsilk disetarakan dengan sampo Hazeline dengan alasan perbedaan merek tersebut merupakan teknik pemasaran untuk diterima di Tiongkok. 


UAD
MIMESIS
Universitas
Ahmad Dahlan

I. Iklan Sampo Sunsilk, Clear, Pantene versi Indonesia

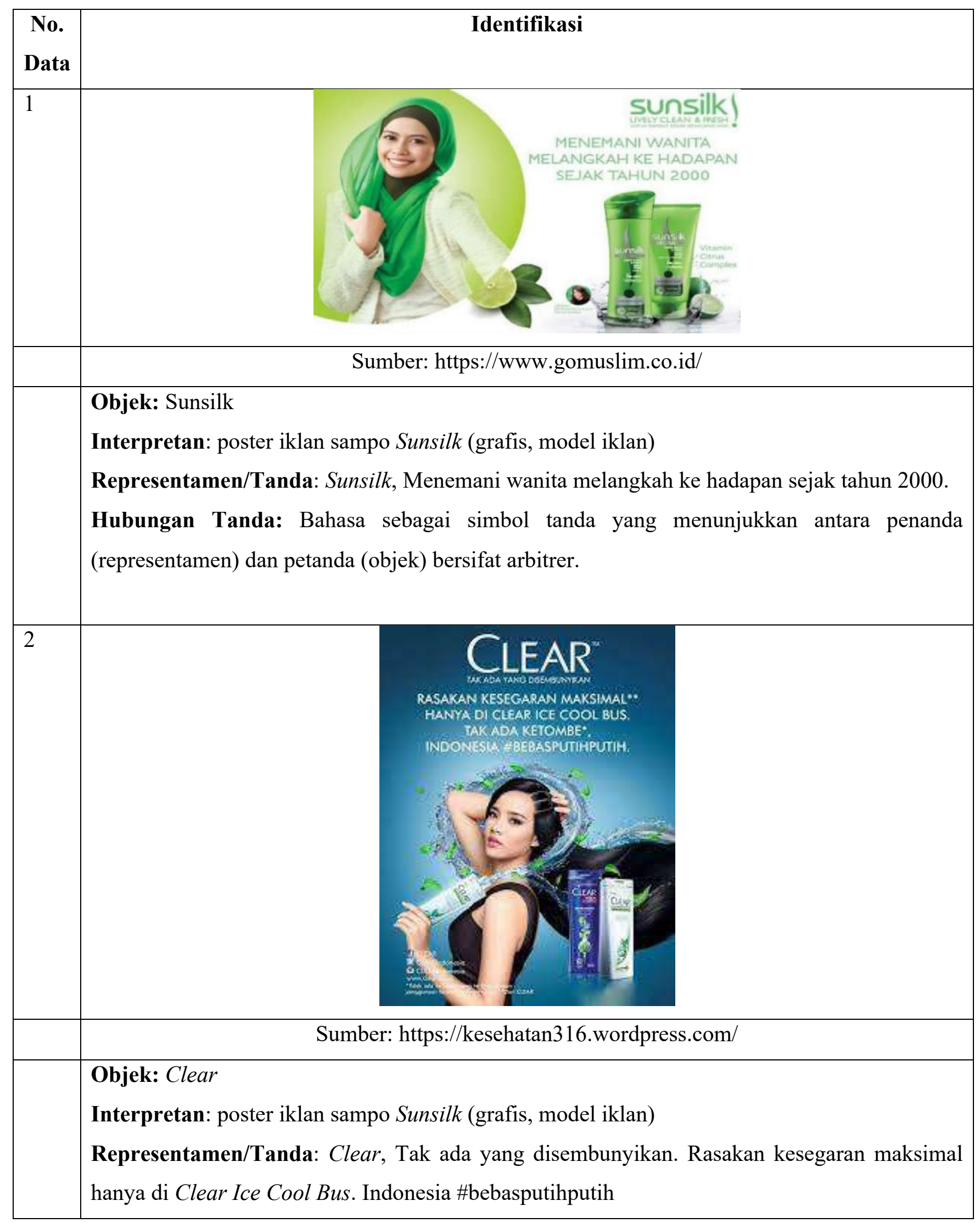




\begin{tabular}{|c|c|c|}
\hline $\begin{array}{l}\text { UAD } \\
\text { Universitas } \\
\text { Ahmad Dahlan }\end{array}$ & $\begin{array}{c}\text { MIMESIS } \\
\text { VoL. 3. No. 1, Januari } 2022\end{array}$ & \\
\hline
\end{tabular}

\begin{tabular}{|l|l|}
\hline & $\begin{array}{l}\text { Hubungan Tanda: Bahasa sebagai simbol tanda yang menunjukkan antara penanda } \\
\text { (Representamen) dan petanda (objek) bersifat arbitrer. }\end{array}$ \\
\hline 3 & $\begin{array}{l}\text { Sumber: https:/shopee.co.id/ } \\
\text { Interpretan: poster iklan sampo Sunsilk (grafis, model iklan) } \\
\text { Representamen/Tanda: Pantene, rambut tanpa batas. Hingga 2x lebih kuat, rambut lebih tebal! } \\
\text { Hubungan Tanda: Bahasa sebagai simbol tanda yang menunjukkan antara penanda } \\
\text { (Representamen) dan petanda (objek) bersifat arbitrer. }\end{array}$ \\
\hline & Pantene
\end{tabular}

Tiga produk sampo tersebut diambil karena mudah ditemukan di Indonesia sehingga menambah akuratan perbedaaan apa saja yang digunakan produk tersebut dalam iklan untuk menarik perhatian masyarakat masing-masing negara. Berdasarkan identifikasi data di atas, berikut pemaparannya.

\section{Data 1: Objek Iklan Sampo Sunsilk.}

Poster iklan tersebut memiliki interpretan wanita menggunakan jilbab warna hijau. Logo Sunsilk yang terletak di bagian atas bertuliskan bahasa Inggris lovely, clear, fresh 'menarik, bersih, segar' yang diberi tanda seru (!), memberi makna bahwa penting untuk diperhatikan bahwa produk Sunsilk akan membuat pemakainya merasa senang, bersih, dan segar. Pemakaian bahasa Inggris pada logo tersebut merupakan strategi perdagangan bahwa Sunsilk merupakan produk kekinian berkelas Indonesia, apalagi bangsa Indonesia gemar menggunakan bahasa asing. Selain jilbab berwarnai hijau yang digunakan model iklan tersebut, terdapat dua gambar produk Sunsilk yaitu sampo dan conditioner, serta buah jeruk nipis yang mengandung vitamin $\mathrm{C}$ yang ditegaskan dengan tulisan di sampingnya. Poster iklan 
ini dominan menggunakan warna hijau, yang menyiratkan kesegaran, didukung dengan tulisan pada logo dan gambar produk pendukung. Jenis tanda/representamen yang digunakan dalam poster iklan tersebut tanda verbal.

Klausa "Menemani wanita melangkah ke hadapan sejak tahun 2000", mengandung kata yang tidak umum, di sini tertulis frasa ke hadapan bukan ke depan. Kedua frasa tersebut memiliki makna hampir sama yaitu ke depan: yang akan datang, pada, muka, depan, sedangkan makna hadapan: ke muka, maju, selanjutnya, seterusnya (https:// lecture-id/arti-hadapan). Setelah frasa ke hadapan diikuti adverbial sejak tahun 2000. Dengan demikian, di balik klausa "Menemani wanita melangkah ke hadapan sejak tahun 2000" mempunyai makna bahwa Sunsilk selalu dipakai para wanita sejak tahun 2000, saat ini, dan waktu yang akan datang.

Interpretan wanita tersenyum yang terlihat segar dan penuh semangat dengan menggunakan jilbab berwarna hijau dianggap mampu mewakili representamen "Sunsilk, menemani wanita melangkah ke hadapan sejak tahun 2000". Faktanya, memang wanita Indonesia banyak yang menggunakan jilbab. Dominan kultural yang ada di suatu negara tentu menjadi salah satu target market suatu produk untuk menarik perhatian. Selain itu, iklan tersebut mampu memengaruhi dan membangun citra para konsumen, bahwa jilbab tidak menghalangi para wanita untuk mengembangkan diri meraih kemajuan. Wanita yang demikian yang ingin melangkah ke masa depan, sejatinya menggunakan sampo Sunsilk karena sampo Sunsilk telah teruji kualitasnya sejak tahun 2000 dan akan tetap dipakai di masa depan.

\section{Data 2: Objek Iklan Sampo Clear.}

Poster iklan tersebut memiliki interpretan wanita berambut panjang yang rambutnya dikelilingi air dan helaian daun yang gugur. Ditambah adanya sampo Clear berwarna biru dan putih. Poster iklan ini dominan menggunakan warna biru. Interpretan tersebut dianggap mampu mewakili representamen yang diinginkan dari produk Sunsilk yakni "Clear, Tak ada yang disembunyikan. Rasakan kesegaran maksimal hanya di Clear Ice Cool Bus. Indonesia \#bebasputihputih". Jenis tanda/representamen yang digunakan dalam poster iklan tersebut adalah simbol yang berupa bahasa yakni bahasa Indonesia.

Representamen kata “\#bebasputihputih” ini menunjukkan bahwa sampo ini berfokus pada penanganan ketombe di rambut. Produk Clear melalui interpretan air dan helaian daun yang ada menunjukkan bahwa menggunakan sampo Clear dapat membuat rambut segar "tak 


\begin{tabular}{|c|c|}
\hline & $\begin{array}{l}\text { UAD } \\
\text { Universitas } \\
\text { Ahmad Dahlan }\end{array}$ \\
\hline
\end{tabular}

ada yang disembunyikan" karena ketombe hilang. Produk Clear di Indonesia dominan menyampaikan manfaat yang diperoleh ketika menggunakan sampo Clear.

\section{Data 3: Objek Iklan Sampo Sunsilk.}

Poster iklan tersebut memiliki interpretan wanita berambut panjang dan lebat. Ditambah adanya sampo Pantene berwarna putih. Poster iklan ini dominan menggunakan warna putih. Interpretan tersebut dianggap mampu mewakili representamen yang diinginkan dari produk Pantene yakni "Pantene, rambut tanpa batas. Hingga 2x lebih kuat, rambut lebih tebal!" Jenis tanda/representamen yang digunakan dalam poster iklan tersebut adalah simbol yang berupa bahasa yakni bahasa Indonesia.

Sangat jelas terlihat bahwa antara interpretan dan representamen sangat berkaitan yakni sama-sama berfokus untuk merawat rambut agar lebih tebal. Representamen "Pantene, rambut tanpa batas..." menunjukkan bahwa sampo Pantene mampu membuat rambut tipismu memiliki kemungkinan untuk lebih tebal dan cantik. Sesuai dengan kultural wanita Indonesia yang menyukai rambut tebal. Jadi, fokus dari iklan ini adalah menyuarakan manfaat dari produk tersebut yang sangat ampuh dalam menebalkan rambut.

II. Iklan Sampo Hazeline, Clear, Pantene versi Tiongkok

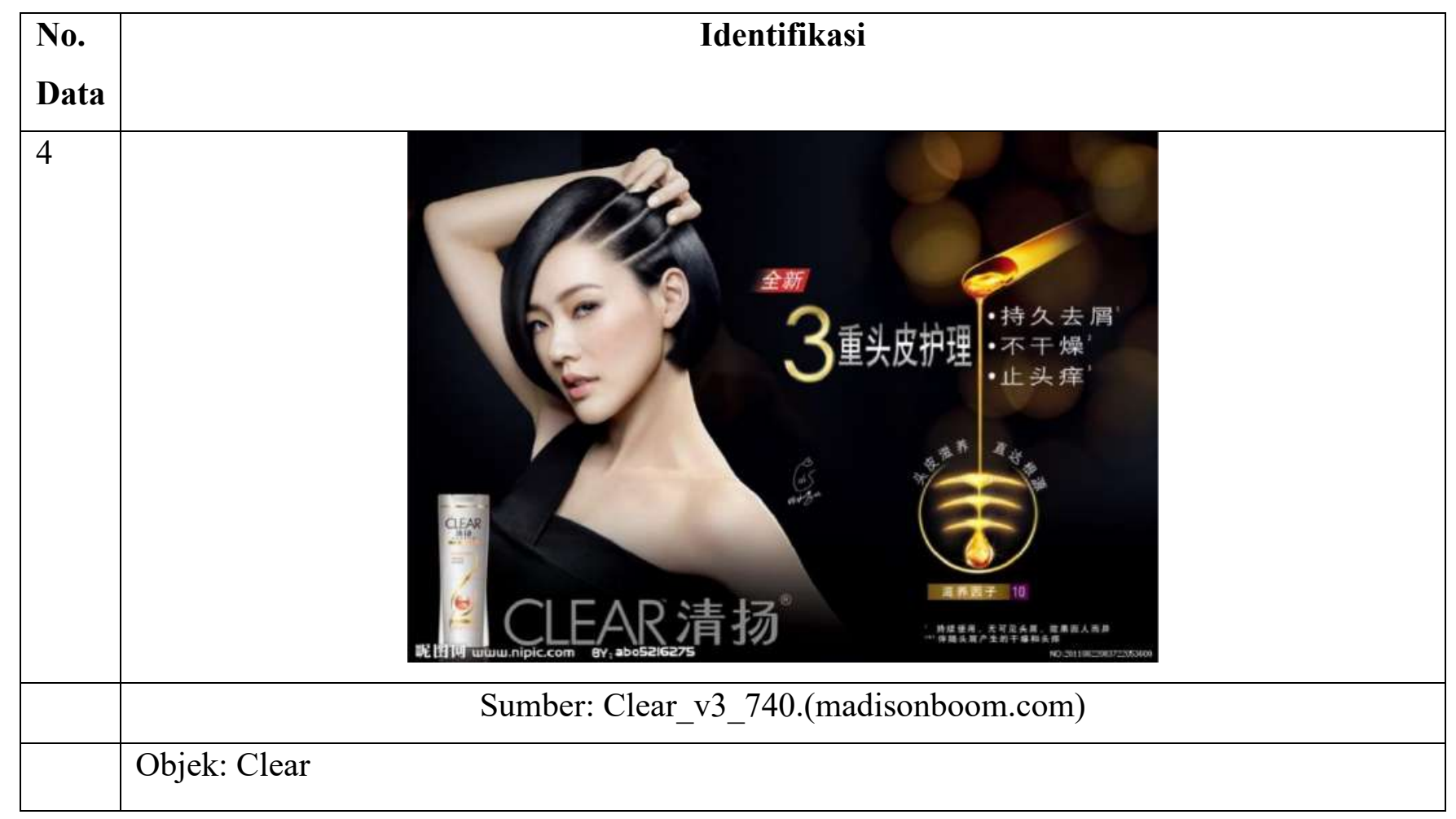




\section{Interpretan: poster iklan sampo Sunsilk (grafis, model iklan)}

Representamen/Tanda:

(1) 3 重头皮护理San chóng tóu pí hù lǐ

/ San chóng tóupí hùlǐ /

/ Tiga kali kulit kepala perawatan /

Terjemahan: 'Perawatan kulit kepala 3 kali lipat'

(2) 持久去屑chí jiŭ qù xiè

/ chí jiǔ qù xiè /

/ tahan lama anti ketombe/

Terjemahan: 'Anti ketombe tahan lama/'

(3) 不干燥 bù gān zào

/ bù gān zào/

/ tidak kering/

Terjemahan: Tidak kering

(4) 止头痒 zhǐ tóu yăng

/ zhǐ tóu yăng /

/ meredakan gatal /

Terjemahan: Meredakan gatal

(5) 头皮滋养 tóu pí zī yăng

/ tóu pí z zī yăng/

/ kulit kepala nutrisi/

Terjemahan: Nutrisi kulit kepala

（6）直达根源 zhi dá gēn yuán

/ zhi dá gēn yuán / 


\begin{tabular}{|c|c|c|}
\hline $\begin{array}{l}\text { UAD } \\
\text { Universitas } \\
\text { Ahmad Dahlan }\end{array}$ & $\begin{array}{c}\text { MIMESIS } \\
\text { VOL. 3. No. 1, Januari } 2022\end{array}$ & $W_{\text {Munssis }}$ \\
\hline
\end{tabular}

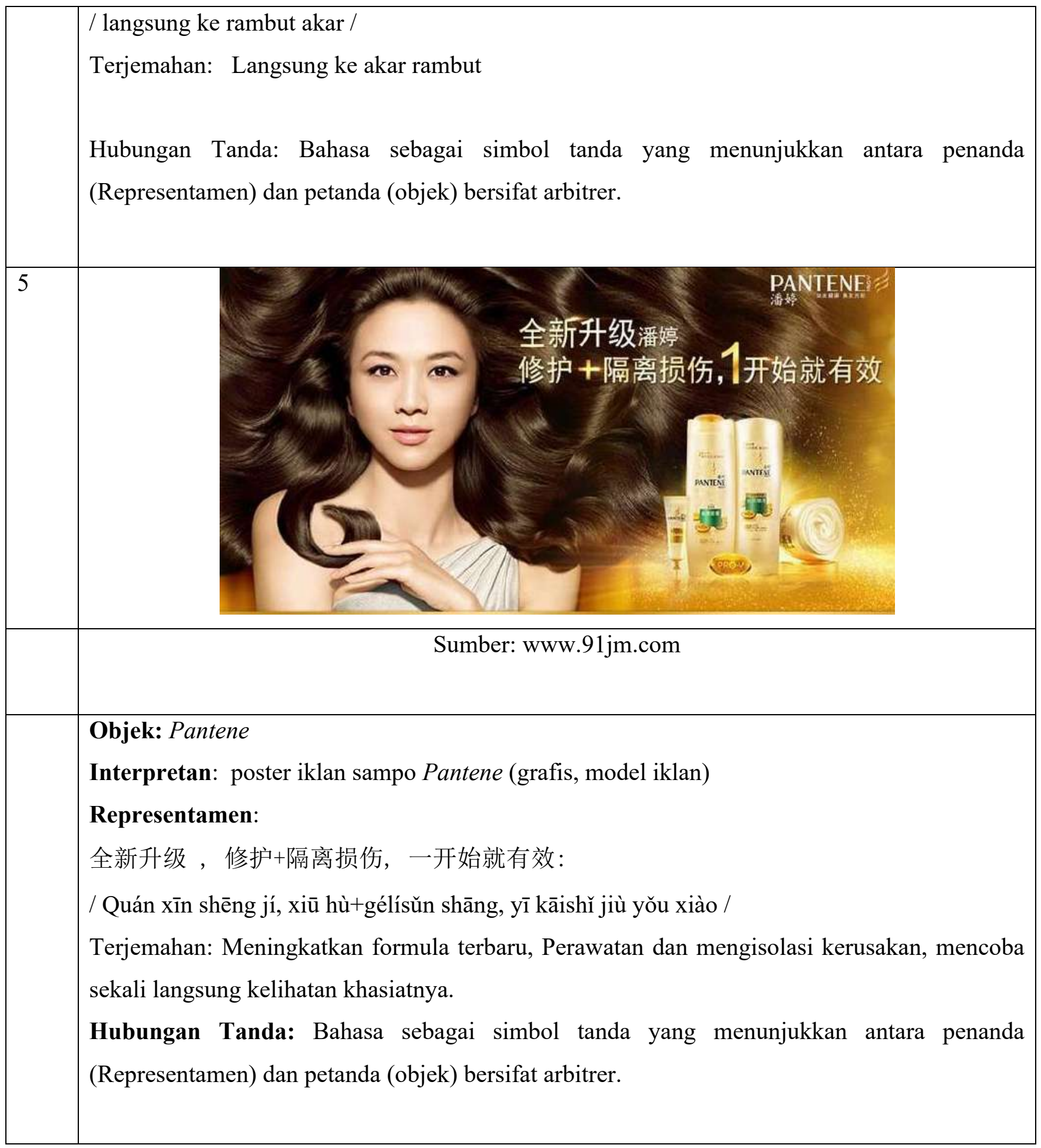




\begin{tabular}{|c|c|}
\hline $\begin{array}{l}\text { UAD } \\
\text { Universitas } \\
\text { Ahmad Dahlan }\end{array}$ & $\begin{array}{c}\text { MIMESIS } \\
\text { VoL. 3. No. 1, Januari } 2022\end{array}$ \\
\hline
\end{tabular}

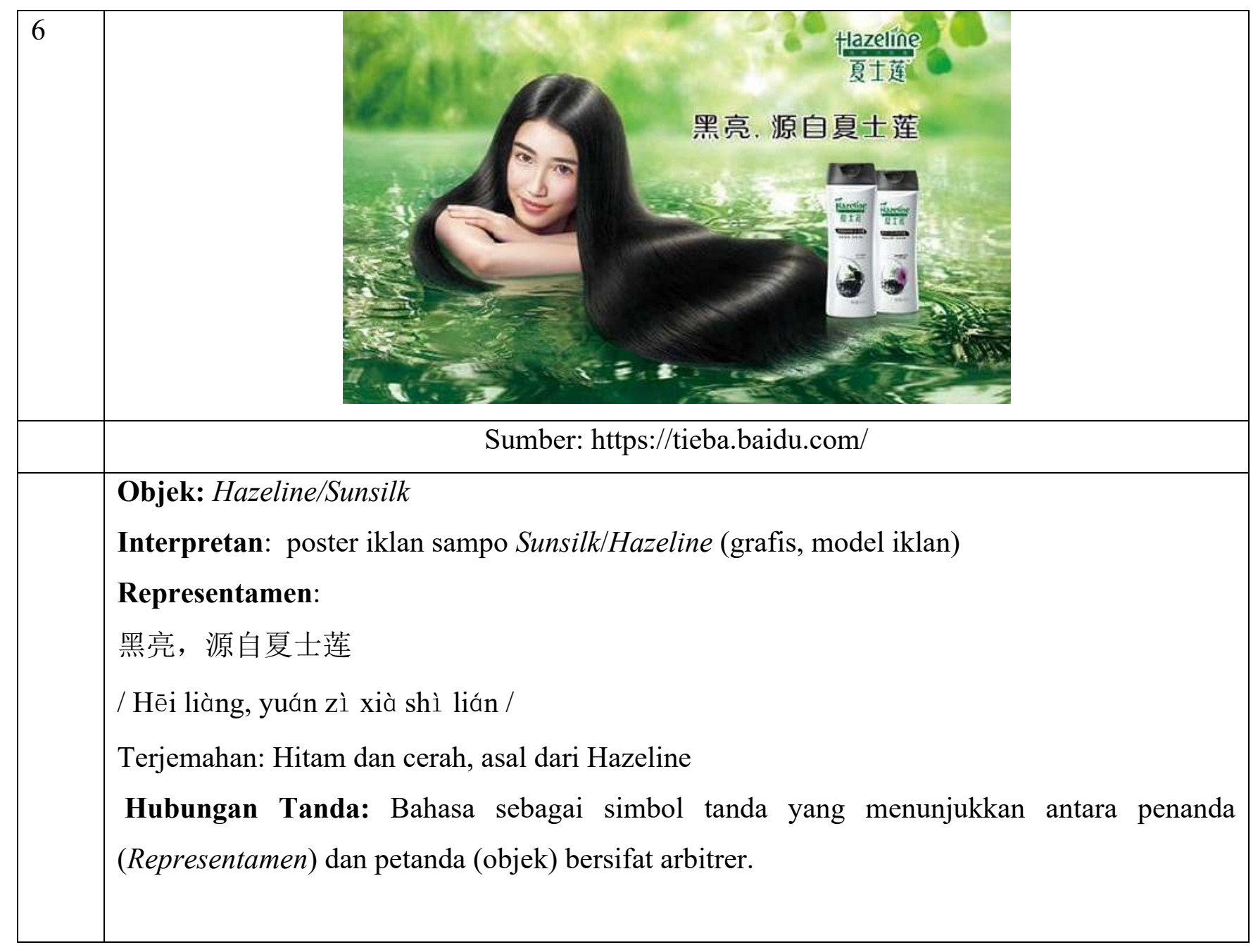

\section{Data 4: Objek Iklan Sampo Clear.}

Interpretan yang sangat mencolok dari iklan tersebut adalah wanita yang berambut pendek dan hitam. Wanita tersebut menggunakan tanggannya untuk menyisir rambut sampai kulit kepalanya terlihat. Dapat dilihat bahwa terdapat tiga belahan kulit kepala di rambutnya. Selain itu, iklan ini menggunakan dominan warna hitam. Interpretan yang sederhana tersebut dianggap mampu mewakili representamen dari "perawatan kulit tiga kali lipat, meliputi anti ketombe tahan lama, tidak kering, meredakan gatal dan menutrisi kulit kepala". Tingkat percaya diri ditunjukkan ketika memperlihatkan belahan kulit kepala rambut wanita tersebut. Hal ini menunjukkan, bahwa dengan menggunakan sampo Clear kita bisa mendapatkan tiga manfaat yang membuat rambutmu lebih indah dan tampil percaya diri.

\section{Data 5: Objek Iklan Sampo Pantene.}




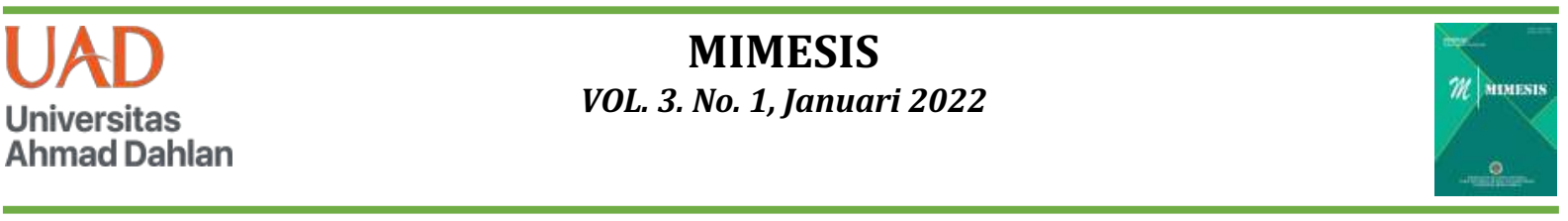

Interpretan yang sangat mencolok dari iklan tersebut adalah wanita yang berambut panjang yang memenuhi setengah iklan. Selain itu, iklan ini menggunakan dominan warna hitam keemasan. Interpretan yang sederhana tersebut dianggap mampu mewakili representamen dari "Meningkatkan formula terbaru, perawatan dan mengisolasi kerusakan, mencoba sekali langsung kelihatan khasiatnya." Representamen tersebut jelas menunjukkan bahwa rambut yang sangat lebat, sehat, dan berkilau bisa didapatkan dengan menggunakan sampo ini. Penggunaan kata "Mencoba sekali langsung kelihatan khasiatnya" juga menambah dan menyikronkan bahwa frasa ini mensugestikan bahwa manfaat tersebut bisa diperoleh secara cepat.

\section{Data 6: Objek Iklan Sampo Sunsilk.}

Interpretan yang sangat mencolok dari iklan tersebut adalah wanita berambut panjang yang berendam di air bewarna hijau. Selain itu, iklan ini menggunakan dominan warna hijau. Interpretan yang sederhana tersebut dianggap mampu mewakili representamen dari "Hitam dan cerah, asal dari Hazeline." Representamen tersebut jelas menunjukkan bahwa rambut yang sehat dan segar dapatdiperoleh dari menggunakan hazeline. Penggunaan kata "Hitam dan cerah, asal dari Hazeline" menunjukkan ketegasan dalam produk ini menyampaikan maksudnya. Iklan ini terlihat singkat dan tegas dalam menyampaikan pesan ke masyarakat.

\section{KESIMPULAN}

Perbandingan Iklan Sampo di Tiongkok dan Indonesia Berdasarkan Analisis Semiotika Pierce memiliki kesimpulan sebagai berikut. Perbandingan iklan sampo Sunsilk, Clear dan Pantene di tiap negara dapat dilihat dari penggunaan interpretan, representamen dalam objek untuk menarik perhatian masyarakat. Berdasarkan tiga uraian di atas menunjukkan bahwa iklan yang dipasang di kedua negara tidak lepas dari budaya. Di Indonesia umumnya para wanita memakai jilbab yang menunjukkan identitas agama Islam, sebagai agama mayoritas orang Indonesia. Hal tersebut ditunjukkan dengan iklan sampo Sunsilk di negara Indonesia. Sebaliknya, iklan sampo Sunsilk di Tiongkok, yang bernama Hazeline, menampilkan wanita berambut, panjang yang indah, yang merupakan ciri wanita Tiongkok sejak lama. Kedua iklan memperlihatkan bahwa masing-masing memperlihatkan karakter masyarakatnya dengan mengangkat aspek budaya. 


UAD
Universitas
Ahmad Dahlan

Selanjutnya, perbandingan iklan sampo Clear di Indonesia dan Tiongkok. Iklan sampo Clear di Indonesia memiliki kecenduragan hanya menyampaikan manfaat yang diberikan saat menggunakan sampo Clear. Penggunaan jargon dalam iklan “\#bebasputihputih" menjadi perhatian khusus untuk membuat masyarakat Indonesia mudah mengingat sampo ini. Namun, berbeda dengan penyampaian iklan sampo Clear di Tiongkok melalui poster memiliki kecenderungan untuk mengunggulkan karakter sampo tersebut yakni karakter percaya diri dengan menggunakan sampo Clear dan fokus kepada tiga manfaat yang diberikan.

Terakhir, perbandingan iklan sampo Pantene, berasarkan dua penjabaran iklan sampo Pantene di atas memiliki teknik iklan yang hampir sama yakni penggunaan kalimat sugesti yang berlebihan. Iklan sampo Pantene di Indonesia mensugestikan bahwa "Pantene, rambut tanpa batas. Hingga 2x lebih kuat, rambut lebih tebal!", sedangkan iklan sampo Pantene di Tiongkok menunjukkan bahwa "Mencoba sekali langsung kelihatan khasiatnya". Kedua representamen tersebut seolah dipaksakan untuk disampaikan kepada masyarakat Indonesia dan Tiongkok. Faktanya, rambut tanpa batas dan mencoba sekali langsung bisa terlihat manfaatnya merupakan pemikiran yang cenderung sulit untuk diterima karena terlalu naif. Hal ini menunjukkan bahwa kedua masyarakat negara tersebut memiliki kecenderungan untuk memeroleh hasil secara instan dan cepat.

\section{DAFTAR PUSTAKA}

Aristyani, I. A. R., \& Yasa, N. N. K. (2013). Perbandingan brand equity roduk sampoo merek Sunsilk dengan merek Pantene. Jurnal Manajemen dan Kewirausahaan. Vol 15.

Dewi, M. C. (2013). Representasi pakaian muslimah dalam iklan, analisis semiotika Charles Sanders Pierce pada iklan kosmetik Wardah di Tabloid Nova. Jurnal Profetik: Jurnal Komunikasi. No 2.

Hoed, B. H. (2011). Semiotik dan dinamika sosial budaya. Komunitas Bambu.

Kasali, R. (1995). Manajemen periklanan, konsep dan aplikasinya di Indonesia. Pustaka Utama Grafiti.

Kridalaksana, H. (1988). Beberapa prinsip perpaduan leksem dalam bahasa Indonesia. Penerbit Kanisius.

Kuswarno, E. (2009). Metode penelitian komunikasi. Widya Padjajaran.

Mohamed, Z. M., Majid, A. H., \& Ahmad, N. (2010). Tapping new possibility in accounting research, in qualitative research in accounting, Malaysian case. Penerbit Universiti Kebangsaan Malaysia.

Nöth, W. (1995). Handbook of semiotics. Indiana University Press.

Piliang, Y. A. (2010). Hipersemiotika: Tafsir Cultural Studies atas Matinya Makna. Jalasutra.

Pondaag, A. F. (2013). Analisis semiotika iklan A Mild Go Ahead versi "Dorong Bangunan" di telivisi. Jurnal Acta Diurna. Vol 1.

Ratna, N. K. (2008). Teori, metode, dan teknik penelitian sastra. Pustaka Pelajar

Sobur, A. (2003). Semiotika komunikasi. Remaja Rosdakarya. 


\begin{tabular}{|c|c|c|}
\hline $\begin{array}{l}\text { Universitas } \\
\text { Ahmad Dahlan }\end{array}$ & $\begin{array}{c}\text { MIMESIS } \\
\text { VoL. 3. No. 1, Januari } 2022\end{array}$ & \\
\hline
\end{tabular}

Wulandari, S. \& Siregar, E.D. (2020). Kajian Semiotika Charles Sanders Pierce: Relasi Trikotomi (Ikon, Indeks dan Simbol) dalam Cerpen Anak Mercusuar Karya Mashdar Zainal. Jurnal Titian: Ilmu Humaniora. Vol 04. No $1 .$.

\section{Sumber Internet}

Muslimah, F. (2016.) "Sunsilk clean and fresh: Cocok untuk perawatan rambut hijaber". Diakses pada https://www.gomuslim.co.id/read/produk/2016/03/14/12/sunsilk-cleanand-fresh-cocok-untuk-perawatan-rambut-hijaber.html

Sebulhocky (2016). "Atasi ketombe anda dengan sampo". Diakses pada laman https://kesehatan316.wordpress.com/2016/11/09/atasi-ketombe-anda-dengan-clearshampo/

Anonim. Tidak ada tahun. "Pantene Shampoo Anti Lepek 290 ml". Diakses pada laman https://shopee.co.id/Pantene-Shampoo-Anti-Lepek-290-mli.11487927.885967236https://shopee.co.id/Pantene-Shampoo-Anti-Lepek-290-mli.11487927.885967236. 